DOI: $10.1590 / 1089-6891 v 20 \mathrm{e}-53193$

MEDICINA VETERINÁRIA

\title{
MINIMUM BACTERICIDAL CONCENTRATION OF COMMERCIAL DISINFECTANTS ON STAPHYLOCOCCUS SPP. ISOLATED FROM MASTITIS IN GOATS AND DETECTION OF THE icaD GENE
}

\author{
CONCENTRAÇÃO BACTERICIDA MÍNIMA DE DESINFETANTES \\ COMERCIAIS FRENTE À STAPHYLOCOCCUS SPP. ISOLADOS DE MASTITE \\ EM CAPRINOS E DETECÇÃO DO GENE icaD
}

\author{
Welington Erasmo de Lima e Silva1 ORCID - http://orcid.org/0000-0002-9159-3168 \\ Evandro Santos Amanso² ORCID - http://orcid.org/0000-0001-7665-8528 \\ Rodolfo de Moraes Peixoto ${ }^{*}$ ORCID - http://orcid.org/0000-0002-5757-5935 \\ João José de Simoni Gouveia² ORCID - http://orcid.org/0000-0002-0438-094X \\ Gisele Veneroni Gouveia² ORCID - http://orcid.org/0000-0003-1074-5711 \\ Mateus Matiuzzi da Costa² ORCID - http://orcid.org/0000-0002-9884-2112

\begin{abstract}
'Universidade Federal do Vale do São Francisco, Petrolina, PE, Brazil.
${ }^{3}$ Instituto Federal do Sertão Pernambucano, Petrolina, PE, Brazil.

*Correspondent author - rodolfo.peixoto@ifsertao-pe.edu.br
\end{abstract} \\ ${ }^{1}$ Faculdade de Ciências Agrárias de Araripina, Araripina, PE, Brazil
}

\begin{abstract}
This study aimed to evaluate the in vitro efficacy of commercial disinfectants on Staphylococcus spp., isolated from mastitis cases in goats, and to associate the observed resistance with the presence of the $i c a \mathrm{D}$ gene. Broth microdilution was employed to evaluate the in vitro antimicrobial activity of the disinfectants, whereas the Congo Red technique was used for the evaluation of biofilm production and amplification of the icaD gene. All evaluated samples were sensitive to disinfectants, with the following ranges of activity: quaternary ammonium $(0.13-21.33 \mu \mathrm{g} / \mathrm{ml})$, chlorhexidine $(4.00-313.00$ $\mu \mathrm{g} / \mathrm{ml})$ and iodine $(190.00-12500.00 \mu \mathrm{g} / \mathrm{ml})$; however, the sodium hypochlorite-based disinfectant showed no bactericidal activity in the concentration range from 15.0 to $0.03 \mu \mathrm{g} / \mathrm{ml}$. The icaD gene presented a frequency of $14.7 \%$ in the isolate samples. Fisher's exact test showed a significant effect of the relation between the minimum bactericidal concentration value of the quaternary ammoniumbased disinfectant and the presence/absence of the icaD gene $(\mathrm{P}<0.01)$. Commercial disinfectants with quaternary ammonium, chlorhexidine and iodine active ingredients presented in vitro activity even at concentrations lower than those recommended by the manufacturers. Therefore, the periodic evaluation of the sensitivity profile of the disinfectants must be performed.
\end{abstract}

Keywords: antimicrobial activity; biofilm; dairy goat; milking; chemical substances

\section{Resumo}

O presente trabalho objetivou avaliar a eficácia in vitro de desinfetantes comerciais frente à Staphylococcus spp. isolados de casos de mastite em cabras e, relacionar a resistência observada com a presença do gene ica $\mathrm{D}$. A microdiluição em caldo foi utilizada para avaliar a atividade antimicrobiana in vitro dos desinfetantes, enquanto a técnica de vermelho congo para a avaliação da produção de biofilme e amplificação do gene icaD. Todas as amostras avaliadas foram sensíveis aos desinfetantes, com as seguintes faixas de atividade: amônia quaternária $(0,13-21,33 \mu \mathrm{g} / \mathrm{ml})$, clorexidina $(4,00$ $313,00 \mu \mathrm{g} / \mathrm{ml})$ e iodo $(190,00-12500,00 \mu \mathrm{g} / \mathrm{ml})$, no entanto o desinfetante a base de hipoclorito de 
sódio não apresentou atividade bactericida na faixa de concentração 15,0 a $0,03 \mu \mathrm{g} / \mathrm{ml}$. O gene icaD apresentou frequência de $14,7 \%$ nos isolados. O teste exato de Fisher apontou efeito significativo da relação entre o valor da concentração bactericida mínima do desinfetante à base de amônia quaternária e a presença/ausência do gene ica $\mathrm{D}(\mathrm{P}<0,01)$. Os desinfetantes comerciais com os princípios ativos amônia quaternária, clorexidina e iodo, apresentaram atividade in vitro até mesmo em concentrações inferiores às preconizadas pelos fabricantes o que torna necessária a realização periódica da avaliação do perfil de sensibilidade dos desinfetantes.

Palavras chave: atividade antimicrobiana; biofilme; caprinos leiteiros; ordenha; produtos químicos

Recebido em: 26 de maio de 2018.

Aceito em: 20 de março de 2019.

\section{Introduction}

Mastitis is a disease of complex etiology characterized by inflammatory alterations of the mammary gland, physical, chemical and bacteriological milk changes, and modifications in the glandular tissue. This disease is associated with economic losses in milk production, also posing an important public health problem ${ }^{(1)}$.

The etiological agents commonly involved in the mastitis of small ruminants are bacteria belonging to the genera Staphylococcus spp., Micrococcus spp., Streptococcus spp., Corynebacterium spp., and Enterobacter spp. ${ }^{(2,3)}$. Among the microorganisms mentioned above, Staphylococcus spp. are identified in higher frequency in intramammary infections of small ruminants. For Marogna et al. ${ }^{(4)}$, among the Staphylococcus spp., the species $S$. aureus is considered the most important, with frequency ranging from $4 \%$ to $40 \%$ of all isolated microorganisms.

The production of natural polysaccharide extracellular substances allows the agglomeration of the bacterial cells in biofilm multilayers, making them less accessible to the defense system of the organism and to antimicrobials ${ }^{(5,6)}$. Among the involved genes, the co-expression of the icaA and ica $\mathrm{D}$ genes results in a significant increase in the production of the polysaccharide involved in biofilm maturation $^{(7)}$.

Several sanitary measures must be adopted during the milking process in order to minimize the transmission of mastitis-causing agents, such as the sanitization of the teats, of the mechanical milking machine and the hand of the milker with an antimicrobial. Besides preventing mastitis, such measures play a significant role in the microbiological quality of the milk. Among the commonly employed disinfectants in the sanitization and disinfection of the milking environment are the quaternary ammonium compounds, as well as the chlorhexidine, chlorine and iodine compounds ${ }^{(8)}$.

Most of the studies related to the antimicrobial activity of disinfectants are aimed at isolates from cases of bovine mastitis, with scarce research on isolates from goat mastitis. The present study aimed to determine the in vitro efficacy of commercial disinfectants employed in the milking environment on Staphylococcus spp., isolated from goats with subclinical mastitis in the state of Pernambuco.

\section{Material and methods}

68 Staphylococcus spp. isolates belonging to the bacterial collection of the Laboratory of Microbiology and Animal Immunology of the Federal University of São Francisco Valley (UNIVASF) were evaluated, which were isolated from the milk of goats with subclinical mastitis in properties of the 
regions of the São Francisco Valley and the coastal area of the state of Pernambuco (Brazil).

The phenotypical evaluation for biofilm production by the isolates of Staphylococcus spp. was performed through the Agar Congo Red (ACR) technique. After the seeding of the samples in the Agar Congo Red culture and the incubation for $24 \mathrm{~h}$ at $37^{\circ} \mathrm{C}$, the colonies that presented a darkened coloring were described as positive for biofilm production(6).

For the evaluation of the genotypic potential for biofilm formation, the amplification of the ica $\mathrm{D}$ gene was performed through Polymerase Chain Reaction (PCR), using an automatic thermocycler (Amplitherm $\left.{ }^{\circledR}\right)$. The following primers were employed in the amplification: (seicaDF) 5'-AAGCCCAGACAGAGGCAATATCCA-3' and (seicaDR) 5'-AGTACAAACAAACTCATCCATCCGA-3', according to the methodology performed by Vasudevan et al.(5) and Greco et al.(6). The thermally-extracted DNA from bacterial isolates in ultrapure water was employed as a template. Two microliters from the extracted DNA were added to $48 \mu \mathrm{l}$ of the PCR mix containing $15 \mathrm{pmol}$ of the primers, $200 \mu \mathrm{M}$ of the deoxyribonucleotides, $1 \mathrm{x}$ Taq buffer and 5U of Taq DNA Polymerase. The PCR comprised the following reaction conditions: 35 cycles composed of $94{ }^{\circ} \mathrm{C}$ for 30 seconds, $55{ }^{\circ} \mathrm{C}$ for 30 seconds and $72{ }^{\circ} \mathrm{C}$ for 3 minutes. The result of the PCR was verified in 1\% agarose gel, stained with ethidium bromide and documented through a photo documentation system.

The activity evaluation of the tested disinfectants on microorganisms isolated from mastitic milk was performed through the liquid-based cytology method and seeding in Mueller-Hinton agar (MHA). The tested concentrations of the disinfectants were those recommended by the manufacturers (Table 1).

Table 1. List of commercial disinfectants employed in mastitis prevention as to their composition and indications described by the manufacturers.

\begin{tabular}{|c|c|c|c|}
\hline Products & Composition & Indication/manner of use & $\begin{array}{c}\text { Range of } \\
\text { concentration } \\
\text { employed in } \\
\text { the study } \\
(\mu \mathrm{g} / \mathrm{ml})\end{array}$ \\
\hline A & $\begin{array}{l}\text { Alkyl dimethyl benzyl } \\
\text { ammonium chloride } 30 \mathrm{~g} \text {, } \\
\text { Polyoxyethylene Nonylphenyl } \\
\text { Ether } 5 \mathrm{~g} \text { and } 100 \mathrm{ml} \text { q.s. } \\
\text { vehicle. }\end{array}$ & $\begin{array}{l}\text { Disinfection of mechanical } \\
\text { milking machines, udders } \\
\text { and hand of the milker. } \\
\text { Dilute in water in a } 1: 2000 \\
\text { proportion. }\end{array}$ & 300 to 0.125 \\
\hline B & $\begin{array}{l}\text { Chlorhexidine di-gluconate } \\
(1 \%) \text {, thickeners, non-ionic } \\
\text { surfactants, emollient and } \\
\text { moisturizing agents. }\end{array}$ & Pre-dipping. Ready to use. & 10,000 to 4.0 \\
\hline C & $\begin{array}{l}\begin{array}{l}\text { Sodium Hydroxide, Sodium } \\
\text { Hypochlorite } \\
\text { Surfactants, Sequestering }\end{array} \\
\text { agents, Corrosion Inhibitors. }\end{array}$ & $\begin{array}{l}\text { Milking machines, } \\
\text { pasteurizers, circuits, milk } \\
\text { processing plants in general. } \\
\text { Dilute } 25 \mathrm{ml} \text { of the product } \\
\text { in } 10 \mathrm{~L} \text { of water. }\end{array}$ & 15.0 to 0.03 \\
\hline $\mathrm{D}$ & $\begin{array}{l}\text { 5ml PVP-Iodine ( } 5000 \mathrm{ppm} \text { of } \\
\text { titratable iodine), } 100 \mathrm{ml} \\
\text { excipient q.s. }\end{array}$ & $\begin{array}{l}\text { No pre-dipping. It is } \\
\text { recommended to dilute } 1 \mathrm{~mL} \\
\text { of the detergent in } 3 \mathrm{~mL} \text { of } \\
\text { water. Ready to use in post- } \\
\text { dipping }\end{array}$ & 50,000 to 20 \\
\hline
\end{tabular}


The samples were transferred from microtubes with a Brain Heart Infusion broth (BHI) with glycerol (70:30) to agar plates with 5\% sheep blood with the aid of a platinum inoculating wire loop and incubated at $37^{\circ} \mathrm{C}$ for $24 \mathrm{~h}$. The determination of the in vitro antimicrobial activity of the commercial disinfectants followed the recommendations of the Clinical and Laboratory Standard Institute (CLSI, $2005)^{(9)}$. The commercial disinfectants were diluted in $200 \mu \mathrm{L}$ of Mueller Hinton broth (MH). A bacterial suspension with turbidity equivalent to the tube corresponding to 0.5 of the McFarland standards was employed. From this suspension, $10 \mu \mathrm{L}\left(1 \times 10^{4} \mathrm{UFC}\right)$ were inoculated in each microtube containing the dilution of the commercial disinfectant. The material was incubated at $37^{\circ} \mathrm{C}$ for $24 \mathrm{~h}$, in aerobiosis conditions. From the dilutions, a $10 \mu \mathrm{L}$ aliquot was removed from the sample in which no visible bacterial growth was verified, sowing it on the $\mathrm{MH}$ agar surface and incubating it for $24 \mathrm{~h}$ at $37{ }^{\circ} \mathrm{C}$. Afterward, the minimal bactericidal concentration (MBC) was determined as the lowest concentration of the commercial disinfectant in study able to cause the death of the inoculum. The assays were performed in triplicate.

Descriptive statistics was used for the results of the in vitro sensitivity profile, with the distribution of the values in percentage. The concordance analysis of the results of the phenotypic and genotypic tests related to biofilm formation was performed through the calculation of the Kappa coefficient. The MBC was considered as the value that repeated twice in the triplicate. The Mann-Whitney test was performed to compare the $\mathrm{MBC}$ values obtained for the positive and negative biofilm isolates.

\section{Results and Discussion}

The result of the in vitro sensitivity profile of the Staphylococcus spp. samples isolated from mastitic goats indicated $100 \%$ sensibility to the disinfectants: quaternary ammonium (A), chlorhexidine (B) and iodine (D) when used in the concentrations recommended by the manufacturers (Table 2). On the contrary to the tested disinfectants, disinfectant $\mathrm{C}$ (sodium hypochlorite) showed to be inefficient in the concentration indicated by the manufacturer $(15 \mu \mathrm{g} / \mathrm{ml})$. A similar result was found by Medeiros et al. ${ }^{(8)}$, studying the efficacy of commercial disinfectants used in pre and post-dipping on samples of Staphylococcus spp. from dairy cattle, for which they observed $100 \%$ of in vitro activity for iodine, $93.3 \%$ for chlorhexidine, $80 \%$ for quaternary ammonium and $100 \%$ resistance to chlorine.

Table 2: Sensitivity of Staphylococcus spp. cultivated from goat mastitis samples to four commercial disinfectants indicated for the milking environment.

\begin{tabular}{ccc}
\hline Disinfectants & Active ingredient & $\begin{array}{c}\text { Observed activity } \\
\text { (\%) }\end{array}$ \\
\hline A & Ammonium & $100(68 / 68)$ \\
B & Chlorhexidine & $100(68 / 68)$ \\
C & Sodium Hypochlorite & $0(0 / 68)$ \\
D & PVP-Iodine & $100(68 / 68)$ \\
\hline
\end{tabular}

One of the factors that might explain the high activity of the commercial Disinfectants on mastitiscausing bacteria in goats is the little use of these antimicrobial agents in the milking environment of small properties in the state of Pernambuco. Questionnaires administered to dairy goat producers in the outback of the Pernambuco and Bahia states verify the non-utilization of disinfectants before and after milking management ${ }^{(10)}$. Furthermore, the controlled conditions of the study provide a lower interference of organic contaminants, an important factor for the obtainment of the results in this study. 
The absence of activity of the sodium hypochlorite on Staphylococcus spp. is primarily due to the low concentration indicated by the manufacturer for the use in milking machines, pasteurizers, circuits and milking producing plants in general. According to Fonseca \& Santos ${ }^{(11)}$, the concentrations of $2 \%$ and $4 \%$ of sodium hypochlorite are the most recommended at pre and post-dipping, respectively. Some studies performed in the last years have observed a constant absence of activity of chlorine sources, such as sodium hypochlorite, as a controlling agent of mastitis-causing microorganisms ${ }^{(8,12)}$. Conversely, the potential of chlorine-based products is important in the removal of mineral aggregates and of the biofilm itself in milk industry equipment.

As for the sensitivity profile of the microorganisms from dairy flocks, testing the specific concentrations of the manufacturers, studies on this theme are scarce. Medeiros et al. ${ }^{(13)}$, when studying risk factors associated to mastitis, observed that the poor milking management, the lack of teat washing and the manual washing of milking equipment are risk factors associated to the positivity of microbiological milk examination.

Out of the 68 Staphylococcus spp. evaluated samples, $8.8 \%(\mathrm{n}=6)$ were identified as phenotypically biofilm-producing through the Agar Congo Red technique, and only three of such isolates amplified the $i c a \mathrm{D}$ gene. Seven other samples which were phenotypically negative for biofilm production through the ACR technique were genotypically characterized as biofilm producers through the amplification of the ica $\mathrm{D}$ gene, totaling $14.7 \%(\mathrm{n}=10)$ of the studied samples. The concordance analysis between the two tests relative to the Kappa index was 0.30, suggesting a weak relation between each other.

A parcel of the isolates evaluated in this work suggested a genetic potential for the formation of biofilm with possible pathogenicity, although with negative results in the phenotypic test. A similar result was found by Ciftci et al. ${ }^{(15)}$ when studying the resistance and biofilm production by Staphylococcus isolates in mastitis cases, in which they observed the lack of correlation between the Agar Congo Red and the PCR techniques for the icaA and ica Denes. According to Gerke et al. ${ }^{(14)}$, the presence of the icaD gene in Staphylococcus leads to a phenotypic expression and a significant increase in the production of capsular polysaccharides involved in biofilm formation. However, other genes are also involved in this process and might have greater importance in the biofilm installation of these isolates.

The phenotypic method for detection of biofilm formation presents a greater subjectivity than the genotypic test, as well as some intrinsic variations of the employed techniques. The ACR test reading of this study was performed $24 \mathrm{~h}$ after the cultivation in Agar Congo Red medium. However, a study conducted by Arciola et al. ${ }^{(16)}$, demonstrates that there is a variation as to the time of the reading after the culturing between species of the genus Staphylococcus.

According to Clutterbuck et al. ${ }^{(17)}$, the organization of the bacterial cells through a biopolymer matrix (biofilm) can be developed by several pathogens of veterinary interest, such as $S$. aureus, Pseudomonas aeruginosa, and Aeromonas hydrophila. A study performed by Oliveira et al. ${ }^{(18)}$ suggested that the biofilm produced by bacteria of the genus Staphylococcus in cases of mastitis is related to the chronicity of intramammary infections. Furthermore, this work revealed a pathogenic potential of $14.7 \%(\mathrm{n}=10)$ for biofilm production in samples of Staphylococcus spp. isolated from goats in the state of Pernambuco. However, the results suggest that other genes might be involved in the process of biofilm formation.

The means of the minimal bactericidal concentrations of the quaternary ammonium and chlorhexidine disinfectants on Staphylococcus spp. were $8.44 \mu \mathrm{g} / \mathrm{ml}$ and $41.88 \mu \mathrm{g} / \mathrm{ml}$, respectively. The MBC values for iodine varied from $190 \mu \mathrm{g} / \mathrm{ml}$ to $12,500 \mu \mathrm{g} / \mathrm{ml}$, with a mean of $5,148 \mu \mathrm{g} / \mathrm{ml}$ (Table 3). It was not possible to calculate the $\mathrm{MBC}$ of the sodium hypochlorite since the dose recommended by the 
manufacturer did not present bactericidal activity in the evaluated samples.

Table 3: Means of the minimal bactericidal concentration $(\mu \mathrm{g} / \mathrm{ml})$ according to the presence of the icaD gene and the range of activity of the commercial disinfectants on Staphylococcus spp. isolated from subclinical goat mastitis.

\begin{tabular}{|c|c|c|c|}
\hline \multirow{2}{*}{ Disinfectant } & \multicolumn{2}{|c|}{ Staphylococcus spp. } & \multirow[t]{2}{*}{ Range of activity $(\mu \mathrm{g} / \mathrm{ml})$} \\
\hline & $i c a \mathrm{D}(-)$ & $i c a \mathrm{D}(+)$ & \\
\hline A (Ammonium) & $9.49^{2}$ & $2.31^{b}$ & $0.13-21.33$ \\
\hline B (Chlorhexidine) & $46.22^{2}$ & $16.67^{2}$ & $4.00-313.00$ \\
\hline $\mathrm{D}$ (Iodine) & $5,053^{2}$ & $5,703^{2}$ & $190.00-12,500.00$ \\
\hline
\end{tabular}

* Different letters between columns indicate statistical difference by the Mann-Whitney test $(p<0.05)$.

A study revealed that the quaternary ammonium compounds present higher efficacy on gram-positive bacteria. As for the chlorhexidine digluconate, it presents in vitro activity on gram-positive and gramnegative bacteria, as well as on fungi ${ }^{(19)}$. Pedrini \& Margatho ${ }^{(20)}$, studying the sensibility of contagious and environmental mastitis-causing microorganisms to disinfectants, observed that the $1 \%$ and $2 \%$ iodine presented high in vitro activity on pathogenic microorganisms isolated from mastitis cases, followed by chlorhexidine.

Only the ammonium MBC presented a significant relation as to the presence/absence of the icaD gene. On the contrary to the expected, the tested Staphylococcus spp. isolates containing the icaD gene showed to be more susceptible to the quaternary ammonium than the bacteria that did not contain the icaD gene. These data are contrary to those described by Moretro et al. ${ }^{(21)}$, when they evaluated the relation between the presence of the icaA gene and the resistance to quaternary ammonium compounds in isolated Staphylococcus spp. in the food industry. This fact might be indicative that the remaining factors besides the ica $\mathrm{D}$ gene may be involved in the bacterial resistance to ammoniumbased disinfectants. Langoni et al. ${ }^{(22)}$ alert to the importance of disinfection processes in the control of contagious and environmental mastitis in goats. With regard to the susceptibility to chlorhexidine and iodine, the test did not suggest a relation between the MBC values and the presence/absence of the ica $\mathrm{D}$ gene $(\mathrm{P}>0,05)$.

\section{Conclusion}

The commercial disinfectants with the quaternary ammonium, chlorhexidine and iodine active ingredients presented the best in vitro activities on the goat mastitis samples of Staphylococcus spp. The same did not occur with the sodium hypochlorite. However, the data obtained in the present study do not allow to establish a relation between the resistance to the disinfectants and the biofilm production in the isolates. However, the periodic performing of the sensitivity profile of the disinfectants is of fundamental importance. Nevertheless, the periodic performing of the sensitivity profile of the disinfectants is of fundamental importance, as well as to know the concentrations of each product before employing them in the programs of mastitis control and milk quality.

\section{Acknowledgments}

To the CNPq (National Council of Scientific and Technologic Development) and to the UNIVASF (Federal University of São Francisco Valley) for the concession of the scientific initiation scholarship 
to the student Welington Erasmo de Lima Silva.

\section{References}

1. Heikkilä AM, Nousiainen JI, Pyörälä S. Costs of clinical mastitis with special reference to premature culling. Journal of Dairy Science. 2012; 95, 139-150.

2. Koop G, De Vliegher S, De Visscher A, Supré K, Haesebrouck F, Nielen M, Van Werven T. Differences between coagulase-negative Staphylococcus species in persistence and in effect on somatic cell count and milk yield in dairy goats. Journal of Dairy Science. 2012; 95, 5075-5084.

3. Mishra, AK, Sharma N, Singh DD, Gururaj K, Abhishek, Kumar V, Sharma DK. Prevalence and bacterial etiology of subclinical mastitis in goats reared in organized farms. Veterinary World. 2018; 11(1), 20-24.

4. Marogna G, Pilo C, Vidili A, Tola S, Schianchi G, Leori S.G. Comparison of clinical findings, microbiological results, and farming parameters in goat herds affected by recurrent infectious mastitis. Small Ruminant Research. 2012; 102, 74- 83.

5. Vasudevan P, Nair MKM, Annamalai TA, Venkitanarayanan KS. Phenotypic and genotypic characterization of bovine mastitis isolates of Staphylococcus aureus for biofilm formation. Veterinary Microbiology. 2003; 92(1-2), 79-185.

6. Greco C, Mastronardi C, Pagotto F, Mack D, Ramirez-Arcos S. Assessment of biofilm-forming ability of coagulase-negative Staphylococci isolated from contaminated platelet preparations in Canada. Transfusion. 2008; 48, 969-977.

7. Arciola CR, Campoccia D, Speziale P, Montanaro L, Costerton JW. Biofilm formation in Staphylococcus implant infections. A review of molecular mechanisms and implications for biofilm-resistant materials. Biomaterials. 2012; 33(26), 5967-5982.

8. Medeiros ES, Santos MV, Pinheiro Junior JW, Faria EB, Wanderley GG, Teles JAA, Mota RA. Avaliação in vitro da eficácia de desinfetantes comerciais utilizados no pré e pós-dipping frente amostras de Staphylococcus spp. isoladas de mastite bovina. Pesquisa Veterinária Brasileira. 2009; 29, 71-75.

9. CLSI (Clinical and Laboratory Standard Institute). Methods for dilution antimicrobial susceptibility tests for bacteria that grow aerobically: Approved standards. Document CLSI M7A-7, CLSI, Wayne, Pennsylvania, 2005.

10. Peixoto RM, Amanso ES, Cavalcante MB, Azevedo SS, Pinheiro Junior JW, Mota RA, Costa, MM. Fatores de risco para mastite infecciosa em cabras leiteiras criadas no estado da Bahia. Arquivos do Instituto Biológico. 2012; 79, 101-105.

11. Fonseca LFL, Santos MV. Qualidade do Leite e Controle de Mastite. Lemos Editorial, São Paulo. 2000. $175 \mathrm{p}$.

12. Amaral LA, Romano APM, Nader Filho A, Rossi Jr OD. Avaliação da eficiência da desinfecção de teteiras e dos tetos no processo de ordenha mecânica de vacas. Pesquisa Veterinária Brasileira. 2004; 24, 173-177.

13. Medeiros ES, Freitas MFL, Saukas TN, Azevedo SS, Pinheiro Junior JW, Brandespim DF, Souza Neto OL, Mota RA. Risk factors associated with buffalo mastitis in the Brazilian Northeast. Pesquisa Veterinária Brasileira. 2011; 31, 499-504.

14. Gerke C, KraftA, Sussmuth R, SchweitzerO, GotzF. Characterization of the N-acetylglucosaminyltransferase activity involved in the biosynthesis of the Staphylococcus epidermidis polysaccharide intercellular adhesin. 
The Journal of Biological Chemistry. 1998; 273, 18586-18593.

15. Ciftci A, Findik A, Onuk EE, Savasan S. Detection of methicillin resistance and slime factor production of Staphylococcus aureus in bovine mastitis. Brazilian Journal of Microbiology. 2009; 40, 254-261.

16. Arciola CR, Baldassarri L, Montanaro L. Presence of icaA and icaD Genes and Slime Production in a Collection of Staphylococcal Strains from Catheter-Associated Infections. Journal of Clinical Microbiology. $2001 ; 39,2151-2156$.

17. Clutterbuck AL, Woods EJ, Knottenbelt DC Clegg PD, Cochrane CA, Percival SL. Biofilms and their relevance to veterinary medicine. Veterinary Microbiology. 2007; 121, 1-7.

18. Oliveira M, Nunes SF, Carneiro C, Bexiga R, Bernardo F, Vilela CF. Time course of biofilm formation by Staphylococcus aureus and Staphylococcus epidermidis mastite isolates. Veterinary Microbiology. 2007; 124, 187-191.

19. Cerqueira MCM. Anti-sepsia princípios gerais e anti-sépticos. In: Rodrigues EAC. Infecções hospitalares prevenção e controle. São Paulo: Sarvier. 1997. Cap.4, 426-434.

20. Pedrini SCB, Margatho LFF. Sensibilidade de microrganismos patogênicos isolados de casos de mastite clínica em bovinos frente a diferentes tipos de desinfetantes. Arquivos do Instituto Biológico. 2003; 70, 391395.

21. Moreto T, Hermansen L, Holck AL, Sidhu MS, Rudi K, Langsrud S. Biofilm formation and the presence of the intercellular adhesion locus ica among staphylococci from food and processing environment. Apllied Enviroment Microbiology. 2003; 69, 5648-5655.

22. Langoni H, Domingues PF, Baldini S. Mastite caprina: seus agentes e sensibilidade frente a antimicrobianos. Revista Brasileira Ciência Veterinária. 2006; 13, 51-54. 